Research article

\title{
The symbiosis between Nicotiana tabacum and the endomycorrhizal fungus Funneliformis mosseae increases the plant glutathione level and decreases leaf cadmium and root arsenic contents
}

\author{
Francesca Degola $^{a, 1}$, Laura Fattorini ${ }^{\text {b, } 1}$, Elisa Bona ${ }^{\text {c, } 1}$, Christian Triscari Sprimuto ${ }^{\text {a }}$ \\ Emanuele Argese ${ }^{\mathrm{d}}$, Graziella Berta ${ }^{\mathrm{c}}$, Luigi Sanità di Toppi ${ }^{\text {a, * }}$ \\ a Dipartimento di Bioscienze, Università degli Studi di Parma, Parco Area delle Scienze 11/A, 43124 Parma, Italy \\ b Dipartimento di Biologia Ambientale, “Sapienza” Università di Roma, Piazzale A. Moro 5, 00185 Roma, Italy \\ c Dipartimento di Scienze e Innovazione Tecnologica, Università degli Studi del Piemonte Orientale “A. Avogadro”, Viale T. Michel 11, 15121 Alessandria, Italy \\ d Dipartimento di Scienze Molecolari e Nanosistemi, Università di Venezia “Ca' Foscari”, Dorsoduro 2137, 30123 Venezia, Italy
}

\section{A R T I C L E I N F O}

\section{Article history:}

Received 10 February 2015

Received in revised form

1 April 2015

Accepted 6 April 2015

Available online 7 April 2015

\section{Keywords:}

AM fungi

Arsenic

Cadmium

Cigarettes

Glutathione

Mycorrhiza

Smoking

Tobacco

\begin{abstract}
A B S T R A C T
Over time, anthropogenic activities have led to severe cadmium (Cd) and arsenic (As) pollution in several environments. Plants inhabiting metal(loid)-contaminated areas should be able to sequester and detoxify these toxic elements as soon as they enter roots and leaves. We postulated here that an important role in protecting plants from excessive metal(loid) accumulation and toxicity might be played by arbuscular mycorrhizal (AM) fungi. In fact, human exploitation of plant material derived from Cd-and As-polluted environments may lead to a noxious intake of these toxic elements; in particular, a possible source of Cd and As for humans is given by cigarette and cigar smoke. We investigated the role of AM fungus Funneliformis mosseae (T.H. Nicolson \& Gerd.) C. Walker \& A. Schüßler in protecting Nicotiana tabacum L. (cv. Petit Havana) from the above-mentioned metal(loid) stress. Our findings proved that the AM symbiosis is effective in increasing the plant tissue content of the antioxidant glutathione (GSH), in influencing the amount of metal(loid)-induced chelators as phytochelatins, and in reducing the $\mathrm{Cd}$ and As content in leaves and roots of adult tobacco plants. These results might also prove useful in improving the quality of commercial tobacco, thus reducing the risks to human health due to inhalation of toxic elements contained in smoking products.
\end{abstract}

() 2015 Elsevier Masson SAS. All rights reserved.

\section{Introduction}

Arsenic (As), a metalloid belonging to the group VA of the periodic table, and cadmium (Cd), a transition metal of the group IIB, are very toxic pollutants released from natural and, mostly, anthropogenic sources (Nagajyoti et al., 2010). Neither Cd and As are essential elements for plants (Mertz, 1981), but they may be easily absorbed through the root system by using the same transporters of some essential nutrients, and then accumulated in planta, thus entering the food chain (Verbruggen et al., 2009). In addition to food, smoking can represent a relevant source of $\mathrm{Cd}$ and

Abbreviations: AM, arbuscular mycorrhiza; Fm, Funneliformis mosseae; GSH, reduced glutathione; PC, phytochelatin.

* Corresponding author.

E-mail address: luigi.sanita@unipr.it (L. Sanità di Toppi).

1 Contributed equally to this work and should be considered co-first authors.
As for humans, and the constant inhalation of these carcinogenic elements, i.e. from cigarette/cigar smoke, can be a cause of severe diseases (Bernard, 2008; IARC, 2012).

Normal levels of $\mathrm{Cd}$ in uncontaminated soils range from 0.01 to $0.7 \mathrm{mg} / \mathrm{kg}$ (Nagajyoti et al., 2010; Sanità di Toppi and Gabbrielli, 1999), but this threshold is often exceeded because of several human activities. $\mathrm{Cd}^{2+}$ competes with other cations for root intracellular access, using the same membrane transporters for the uptake of essential ions, such as $\mathrm{Ca}^{2+}, \mathrm{Fe}^{2+}, \mathrm{Mg}^{2+}, \mathrm{Cu}^{2+}$ and $\mathrm{Zn}^{2+}$ (Papoyan et al., 2007; Roth et al., 2006). Damage caused by Cd in plant tissues may be partly correlated to its high affinity with thiol (SH) groups of structural proteins and enzymes, whose functional structure and activity and/or redox regulation can be totally compromised by this metal. In non-hyperaccumulator plants [i.e., plants which are not able to translocate and accumulate very high concentrations of one or more metal(loid)s in the shoots without showing severe toxicity symptoms (Baker et al., 2000)], the main 
detoxification mechanism of $\mathrm{Cd}$ is the complexation with thiolpeptides and the subsequent sequestration in the vacuoles of root cells (Verbruggen et al., 2009). Acropetal Cd translocation from root to shoot takes place through the xylem vascular elements, following the transpiration-driven water flow, possibly both in free and complexed form, such as Cd-organic acids or Cdphytochelatins, as suggested by Senden et al. (1995) in tomato, and by Gong et al. (2003) in Arabidopsis thaliana, respectively.

Arsenic is present in soil essentially in the form of inorganic compounds, i.e. arsenate $\left(\mathrm{As}^{\mathrm{V}}\right)$ and arsenite $\left(\mathrm{As}^{\mathrm{III}}\right)$ : the former is the main form in aerobic soils (Zhao et al., 2009), where tobacco and most plants grow. Arsenate is an analog of phosphate $\left(\mathrm{P}_{\mathrm{i}}\right)$ and competes with it for the uptake by plant roots through membrane $P_{i}$ transporters (Meharg and Macnair, 1990, 1992); arsenite is more mobile in the soil, and is instead absorbed through $P_{i}$-independent mechanisms (Verbruggen et al., 2009). Inside the plant tissues, arsenate may interfere with phosphate metabolism, replacing it in ATP molecules, whereas arsenite may inactivate several enzymes because of its high affinity for SH groups (Talano et al., 2014). Plants may detoxify $\mathrm{As}^{\mathrm{V}}$ by reducing it to $\mathrm{As}{ }^{\mathrm{III}}$, which can be then subtracted from cytosol by complexation with thiol-peptides, such as the tripeptide glutathione in its reduced form (GSH) and its derivatives (Raab et al., 2004; Verbruggen et al., 2009), as is the case with Cd ions (see below). However, in As-non-hyperaccumulating plants, a large fraction of As ${ }^{\mathrm{III}}$ may be also removed from the root through an efflux mechanism (Verbruggen et al., 2009; Xu et al., 2007). In these plants, $A s^{\text {III }}$ seems to be the main form transported in xylem sap, as demonstrated in tomato by Xu et al. (2007).

Plants may adopt different strategies to counteract toxicity caused by metal(loid) exposure, both at cytological and at molecular and biochemical level. A common mechanism is the synthesis of phytochelatins (PCs), Cys-rich thiol-peptides, with the general structure $(\gamma \text {-Glu-Cys) })_{n}$-Gly (with n more commonly ranging from 2 to 5), which are able to chelate various metal(loid)s by their $\mathrm{SH}$ groups, and thus neutralize their harmful effects to some extent (Grill et al., 1985; Yadav, 2010). In response to several metal(loid)s, such as $\mathrm{Cd}, \mathrm{Zn}, \mathrm{Hg}, \mathrm{Cu}, \mathrm{Pb}, \mathrm{As}$, PCs are rapidly synthesized in the cytosol. PC synthesis starts from GSH, and occurs by means of a transpeptidation catalyzed by the constitutively-expressed enzyme phytochelatin synthase (PCS), whose activity is triggered by the presence of metal(loid)s. PC synthesis has not only been detected in higher plants, but also in bryophytes, some algae, yeasts and animals (Petraglia et al., 2014, and references therein). It has been demonstrated that the PC-Cd, GSH-Cd, PC-As ${ }^{\text {III }}$ and GSH-As ${ }^{\text {III }}$ complexes can be transported through the tonoplast into the vacuole and then promptly sequestered in this compartment (Verbruggen et al., 2009). Moreover, PCs and GSH may play an important role in the long-distance $\mathrm{Cd}$ transport between root and shoot, carrying the metal in the form of PC-Cd or GSH-Cd complexes, respectively (Gong et al., 2003; Mendoza-Cózatl et al., 2011). However, the mechanisms that regulate $\mathrm{Cd}$ and As root-to-shoot translocation in tobacco are not completely clear, as they have not been fully investigated at this time.

A protective role from metal(loid) stress in plants may be performed by arbuscular mycorrhizal (AM) fungi (Gamalero et al., 2009; Hildebrandt et al., 2007), belonging to the Phylum Glomeromycota, which establish mutualistic symbiosis with the roots of most land plants. AM fungi improve mineral nutrition of their hosts, in particular by favoring the root absorption of $\mathrm{P}_{\mathrm{i}}$, even in metal(loid)-polluted soils (Göhre and Paszkowski, 2006). In particular, the AM mycorrhizal Glomus spp. may be widespread in the rhizosphere of plants growing in metal(loid)-contaminated soils (Garg and Bhandari, 2014). It has been demonstrated that these fungi may secrete compounds, as the glycoprotein glomalin, which binds the pollutants present in the soil, or may immobilize them by passive adsorption to the hyphae's cell walls (Bedini et al., 2009; González-Chávez et al., 2004); in addition, they may chelate metal(loid)s inside their cells, e.g. possibly by means of metallothioneins (Cys-rich oligopeptides different from PCs). Thus, AMmycorrhized plants often show an enhanced metal(loid) tolerance (Garg and Bhandari, 2014; Göhre and Paszkowski, 2006, and references therein). However, the role of these fungi in the plant uptake and translocation of Cd is not clear, as it is influenced by many factors (Garg and Bhandari, 2014; Janoušková et al., 2005), and there are few data on As, particularly as regards nonhyperaccumulator plants (Hua et al., 2009; Liu et al., 2005). In the As-hyperaccumulator fern Pteris vittata, hosting the AM symbiosis with Glomus mosseae (now renamed Funneliformis mosseae, see the M\&M subsection 2.1.), an increase in both the As translocation factor from roots to fronds and in overall As tolerance, has been shown (Bona et al., 2011; Trotta et al., 2006).

Nicotiana tabacum (tobacco) is a crop featured by an expanded root system, which favors the interception of $\mathrm{Cd}$ and As in the soil. Tobacco is able to accumulate these pollutants both in root and shoot, although it is not a hyperaccumulator species (Keller and Hammer, 2005). Studies on As detoxification by means of PCs or other mechanisms are scarce in this species (Wojas et al., 2010a). Conversely, the synthesis of PCs in tobacco seedlings and young plants, after treatment with $\mathrm{Cd}$, has been demonstrated (Nicotiana rustica: Vögeli-Lange and Wagner, 1990, 1996; N. tabacum: Krystofova et al., 2012; Pomponi et al., 2006; Wojas et al., 2008, 2010b), alongside their ability to promptly detoxify this metal.

It is known that leaves of field-grown tobacco can accumulate relatively high levels of $\mathrm{Cd}$, usually ranging from about 0.5 to $5 \mathrm{mg} \mathrm{kg}^{-1}$ DW (Lugon-Moulin et al., 2004), and the common longterm use of phosphate fertilizers for tobacco production may enhance the metal amount in the soil and, consequently, in the plant organs (Lugon-Moulin et al., 2006b). Plasma mass spectrometry analyses of leaf samples of selected cvs. used for human consumption (i.e.: Flue-cured, Burley and Oriental), collected in several tobacco-producing regions around the world, have detected concentrations of $\mathrm{Cd}$ and As up to $6.78 \mathrm{mg} \mathrm{kg}^{-1} \mathrm{DW}$ and $8.5 \mathrm{mg} \mathrm{kg}^{-1} \mathrm{DW}$, respectively (Lugon-Moulin et al., 2006a, 2008). The greatest damage for human health derives from the direct inhalation of these toxic elements by active and passive smokers (Bernhard et al., 2005; IARC, 2004).

For the reasons just described, it is important to develop a valid natural system for reducing $\mathrm{Cd}$ and As accumulation in tobacco leaves. Until now, little research has been performed on the effects of AM fungi on Cd and As root uptake and leaf accumulation in tobacco. Thus, the hypothesis to be verified in this work is that the AM colonization by the Glomeromycota F. mosseae might limit the root uptake and, above all, the leaf accumulation of $\mathrm{Cd}$ and/or As in adult tobacco plants. The results show the possibility of reducing, through the above mycorrhizal symbiosis, metal(loid) accumulation in tobacco cvs. used for manufacturing cigarettes/cigars and other smoking-derivatives.

\section{Materials and methods}

\subsection{Plant material, growth conditions, metal(loid) treatments, and evaluation of the mycorrhizal colonization}

Seeds of Nicotiana tabacum L. (tobacco, cv. Petit Havana) were sterilized in $10 \%$ sodium hypochlorite for $10 \mathrm{~min}$, carefully washed three times with sterile deionized water, and germinated for 1 week in Vitro Vent vessels (Duchefa Biochemie, Haarlem, NL), on sterile MS medium (Murashige and Skoog, 1962) provided with 1\% sucrose and $1 \%$ agar. Subsequently the sterile plantlets continued to grow in the same vessels for a further 7 weeks, and were then 
transplanted into pots filled with sterile quartz sand, fed everyday with Long Ashton nutrient solution, $\mathrm{pH} 5.6$, containing $32 \mu \mathrm{M}$ phosphorus (in the form $\mathrm{NaH}_{2} \mathrm{PO}_{4}$ ) (Trotta et al., 1996). Half of the plants were inoculated with the arbuscular mycorrhizal (AM) fungus Funneliformis mosseae (T.H. Nicolson \& Gerd.) C. Walker \& A. Schüßler (Schüßler and Walker, 2010) - hitherto named Glomus mosseae (T.H. Nicolson \& Gerd.) Gerd. \& Trappe - and henceforth indicated as Fm, whereas the other half were not. The Fm inoculum (INOQ GmbH, Schnega, Germany) was mixed 10\% (v/v) with sterile quartz sand.

After another 6 weeks of growth in a controlled chamber (16/8 h light/dark photoperiod, $145 \mu \mathrm{mol} \mathrm{m}{ }^{-2} \mathrm{~s}^{-1}$ PPFD and $23 \pm 1{ }^{\circ} \mathrm{C}$ ), 70 non-mycorrhized and 70 mycorrhized tobacco plants were treated with $\mathrm{Cd}$ or $\mathrm{As}^{\mathrm{V}}$, in the forms of $\mathrm{CdCl}_{2}$ and $\mathrm{Na}_{2} \mathrm{HAsO}_{4} \cdot 7 \mathrm{H}_{2} \mathrm{O}$, respectively, dissolved in Long Ashton solution at concentrations of 0 (control treatment), $1 \mu \mathrm{M}$ and $30 \mu \mathrm{M}$ (14 non-mycorrhized plants and 14 mycorrhized plants per each treatment). Following 28 days of $\mathrm{Cd}$ or $\mathrm{As}^{\mathrm{V}}$ exposure, all plants were harvested, thoroughly washed with deionized water, and then separated into roots and leaves. Root and leaf fresh weights (FW) were taken, part of the samples were frozen in liquid nitrogen and placed at $-80{ }^{\circ} \mathrm{C}$ for thiol-peptide analysis; part of the root samples was conserved in $70 \%$ ethanol for mycorrhizal evaluation. The dry weights (DW) of 5 root and leaf samples, cut from 5 non-mycorrhized and 5 mycorrhized plants per treatment, were measured after being dehydrated in an oven at $80{ }^{\circ} \mathrm{C}$ for $12 \mathrm{~h}$. The remaining roots and leaves were dried at $80{ }^{\circ} \mathrm{C}$ for $16 \mathrm{~h}$ and used for metal(loid) concentration analysis.

For evaluation of mycorrhizal colonization, 40 randomly chosen $1 \mathrm{~cm}$-long pieces were cut from tobacco roots, fixed in $70 \%$ ethanol, cleared in $10 \% \mathrm{KOH}$ for $45 \mathrm{~min}$ at $60{ }^{\circ} \mathrm{C}$, stained with $1 \%$ methyl blue in lactic acid and mounted on glass slides for examination under a light microscope. Mycorrhizal colonization was estimated according to Trouvelot et al. (1986).

\subsection{Determination of $\mathrm{Cd}$ and As concentrations in roots and leaves}

For As determination, aliquots of about $0.15 \mathrm{~g}$ of root and leaf samples were completely digested with $2 \mathrm{~mL}$ of concentrated $\mathrm{H}_{2} \mathrm{SO}_{4}, 2 \mathrm{~mL}$ of $30 \% \mathrm{H}_{2} \mathrm{O}_{2}$ and $4 \mathrm{~mL}$ of $\mathrm{H}_{2} \mathrm{O}$ in closed Teflon PFA vessels for $30 \mathrm{~min}$ at $170^{\circ} \mathrm{C}$, using a microwave sample digestion system (CEM MDS 2000) with a maximum operating power of $630 \mathrm{~W}$. The resulting digests were quantitatively transferred into 25-mL volumetric flasks and made up to volume with $\mathrm{H}_{2} \mathrm{O}$. Determination was performed by hydride generation-atomic absorption spectrometry (HG-AAS) using a Varian SpectrAA-250 Plus spectrometer equipped with a Varian VGA-77 vapor generation accessory. For Cd determination, aliquots of about $0.15 \mathrm{~g}$ of plant tissue samples were digested completely with $4 \mathrm{~mL}$ of $\mathrm{H}_{2} \mathrm{O}, 4 \mathrm{~mL}$ of concentrated $\mathrm{HNO}_{3}$ and $4 \mathrm{~mL}$ of $30 \% \mathrm{H}_{2} \mathrm{O}_{2}$ in a closed teflon PFA vessel for $54 \mathrm{~min}$ at $170{ }^{\circ} \mathrm{C}$, using a microwave system with a maximum operating power of $630 \mathrm{~W}$. The resulting digests were quantitatively transferred into $25 \mathrm{~mL}$ volumetric flasks and made up to volume with Milli-Q (Millipore) water. Cd determination was performed by a Varian 250 plus spectrometer equipped with a Varian GTA-96 graphite furnace. The certified reference material used to validate the analytical method and to assess precision and accuracy was a BCR sample of Olea europaea m. G2 (Commission of the European Communities) with a certified concentration of $\mathrm{Cd}$ $\left(0.12 \pm 0.02 \mathrm{mg} \mathrm{kg}^{-1} \mathrm{DW}\right)$ and of As $\left(0.20 \pm 0.02 \mathrm{mg} \mathrm{kg}^{-1} \mathrm{DW}\right)$. The digestion and analysis protocols proved to be reliable and consistent, respectively giving a Cd concentration of $0.13 \pm 0.01 \mathrm{mg} \mathrm{kg}^{-1}$ DW and an As concentration of $0.21 \pm 0.01 \mathrm{mg} \mathrm{kg}^{-1} \mathrm{DW}$.

\subsection{Separation and quantification of thiol-peptides}

Root and leaf samples (300 mg each) were homogenized in a mortar in the presence of ice-cold $5 \%(\mathrm{w} / \mathrm{v})$ 5-sulfosalicylic acid containing $6.3 \mathrm{mM}$ diethylene-triaminepenta-acetic acid (DTPA), mainly following de Knecht et al. (1994). After centrifugation at $10,000 \times \mathrm{g}$ for $10 \mathrm{~min}$ at $4{ }^{\circ} \mathrm{C}$, the supernatants were filtered through Minisart RC4 $0.45 \mu \mathrm{m}$ filters (Sartorius, Goettingen, Germany) and immediately assayed by an autosampler-equipped HPLC system (model 200/225, Perkin-Elmer, Norwalk, CT). Thiol-peptide compounds were separated through a reverse-phase PurospherLiChroCART C18 column (Merck GmbH, Darmstadt, Germany), by injecting $200 \mu \mathrm{L}$ of each extract. Separation was achieved by means of a $0-26 \%$ acetonitrile gradient (Merck, Germany) containing $0.05 \%$ trifluoroacetic acid, at a flow rate of $0.7 \mathrm{~mL} \mathrm{~min}{ }^{-1}$. Thiol-peptide compounds were detected by post-column derivatization with $300 \mu \mathrm{M}$ Ellman's reagent [5,5'dithio(2-nitrobenzoic acid)] at $412 \mathrm{~nm}$ (Series 200 detector, PerkinElmer). Identification of GSH and of the individual oligomers $\mathrm{PC}_{2}$ and $\mathrm{PC}_{3}$ was based on comparing their retention times with standard GSH (Merck) and PC samples from Silene vulgaris (Moench) Garcke. Total PC concentrations were evaluated in roots and leaves in terms of the sum of the oligomers $\mathrm{PC}_{2}$ and $\mathrm{PC}_{3}$. A calibration curve for standard $\mathrm{SH}$ groups was used for quantification of thiol-peptides in extracts.

\subsection{Statistics}

The experiments were conducted in a completely randomized design with five independent replicates $(n=5)$. Data were expressed as means \pm standard error (SE). Results were analyzed by performing two-way analysis of variance (ANOVA), with treatment and mycorrhization (presence/absence of Fm) as factors, followed by LSD test, using the SPSS Statistic 17.0 software package (SPSS Inc., Chicago, US-IL). Different letters indicate significant differences at $\mathrm{p}<0.05$.

\section{Results}

\subsection{Mycorrhizal colonization percentage, metal(loid) concentrations and dry weight measurements of plant organs}

At the end of the pot culture, as useful indicators of the fungal colonization degree, both the percentage of mycorrhizal colonization (M\%) and of arbuscules (A\%), with respect to total intraradical mycelium, were evaluated in mycorrhized (Fm) roots (Table 1A, B). Firstly, we verified that $\mathrm{M} \%$ was 0 in the roots of plants not inoculated with the fungus. M\% was, on average, about $74 \%$ in non-Cd/ $\mathrm{As}^{\mathrm{V}}$-treated mycorrhized plants (controls) (Fm0; Table 1B). The treatments with $A s^{\mathrm{V}}$ did not affect this value, whereas $\mathrm{Cd}$ at 1 and $30 \mu \mathrm{M}$ reduced the mycorrhizal colonization by ca. 30 and $40 \%$, respectively. In addition, $A \%$, equal to about $36 \%$ in control roots, was significantly lowered ( $-55 \%$ and $-60 \%$, respectively) in the presence of 1 and $30 \mu \mathrm{M} \mathrm{Cd}$, while, $\mathrm{A} \%$ did not change significantly with $\mathrm{As}^{\mathrm{V}}$ at both concentrations, thus reflecting a trend similar to $\mathrm{M}$ $\%$ (Table $1 \mathrm{~B}$ ). It is interesting to note that, if compared with the initial value (Table $1 \mathrm{~A}$ ), i.e. just before the metal(loid) treatment (and equal to ca. 43\%), M\% increased in control roots of $70 \%$ after 28 days, while the increase was less than $20 \%$ in roots treated with $1 \mu \mathrm{M} \mathrm{Cd}$, and completely annulled in the presence of $30 \mu \mathrm{M} \mathrm{Cd}$. On the contrary, $\mathrm{As}^{\mathrm{V}}$ at both concentrations seemed not to affect the increase of this parameter over time, when compared with control roots.

In general, $\mathrm{Cd}$ or As concentrations measured in roots and leaves were dependent on the supplied metal(loid) concentrations. In roots of the $30 \mu \mathrm{M}$ Cd-exposed non-mycorrhized plants, the metal 
Table 1

(A) Evaluation of mycorrhizal colonization in tobacco roots 6 weeks after the inoculation with $F$. mosseae, and (B) after further 28 days in the absence (control, Fm0) or in the presence of $1 \mu \mathrm{M} \mathrm{Cd}(\mathrm{FmCd} 1), 30 \mu \mathrm{M} \mathrm{Cd}(\mathrm{FmCd} 30), 1 \mu \mathrm{M} \mathrm{As}{ }^{\mathrm{V}}$ (FmAs 1), $30 \mu \mathrm{M} \mathrm{As} \mathrm{s}^{\mathrm{V}}$ (FmAs 30). M\%, mean percentage of the root system colonized by the fungus; $\mathrm{A} \%$, mean percentage of arbuscules; $\mathrm{V} \%$, mean percentage of vesicles. $\mathrm{M} \%$ was $0 \mathrm{in}$ plants which were not inoculated with the fungus. Mean values $\pm \mathrm{SE}, n=5$. Within each column, different letters indicate significant differences at $\mathrm{p}<0.05$ (two-way ANOVA followed by LSD test).

\begin{tabular}{|c|c|c|c|}
\hline \multicolumn{4}{|c|}{ (A) Initial mycorrhizal colonization } \\
\hline $\mathrm{M} \%$ & & & $43.24 \pm 3.70$ \\
\hline$A \%$ & & & $25.01 \pm 1.51$ \\
\hline \multicolumn{4}{|c|}{ (B) Mycorrhizal colonization at the end of pot culture } \\
\hline Treatment & $\mathrm{M} \%$ & $\mathrm{~A} \%$ & V\% \\
\hline Fm0 & $73.55 \pm 8.57^{\mathrm{a}}$ & $35.78 \pm 12.62^{\mathrm{a}}$ & $41.62 \pm 6.34^{\mathrm{a}}$ \\
\hline FmCd 1 & $51.25 \pm 7.41^{\mathrm{b}}$ & $15.99 \pm 5.65^{\mathrm{b}}$ & $18.37 \pm 4.19^{\mathrm{b}}$ \\
\hline FmCd 30 & $41.24 \pm 6.02^{\mathrm{b}}$ & $13.47 \pm 4.41^{\mathrm{b}}$ & $18.75 \pm 5.82^{\mathrm{b}}$ \\
\hline FmAs 1 & $73.22 \pm 3.26^{\mathrm{a}}$ & $35.58 \pm 3.95^{\mathrm{a}}$ & $33.31 \pm 3.04^{\mathrm{a}}$ \\
\hline FmAs 30 & $69.10 \pm 6.15^{\mathrm{a}}$ & $29.66 \pm 3.70^{\mathrm{a}}$ & $31.96 \pm 11.08^{\mathrm{a}}$ \\
\hline
\end{tabular}

level (up to about $48 \mathrm{mg} \mathrm{kg}^{-1} \mathrm{DW}$ ) did not vary in response to the mycorrhization (Fig. 1A). A clear, although non-significant, downward trend in $\mathrm{Cd}$ content was instead found in Fm plants treated with $1 \mu \mathrm{M}$ Cd with respect to non-mycorrhized ones (Fig. $1 \mathrm{~A}$ ). In leaves of non-mycorrhized plants treated with the highest $\mathrm{Cd}$ concentration, the metal was highly accumulated (up to $107.3 \pm 13.7 \mathrm{mg} \mathrm{kg}{ }^{-1} \mathrm{DW}$ ), and the mycorrhization produced a marked reduction in Cd level of about 40\% (Fig. 1B). Unlike Cd, when supplied at $30 \mu \mathrm{M}$, As was highly accumulated in nonmycorrhized roots $\left(158.0 \pm 10.7 \mathrm{mg} \mathrm{kg}^{-1} \mathrm{DW}\right)$, and the mycorrhization highly reduced the As root presence by about $80 \%$ (Fig. 1C). Vice versa, in leaves, As accumulation was quite low when the metalloid was supplied at $30 \mu \mathrm{M}\left(5.2 \pm 0.9 \mathrm{mg} \mathrm{kg}^{-1} \mathrm{DW}\right.$ in nonmycorrhized plants), with no difference given by the mycorrhization at each $\mathrm{As}^{\mathrm{V}}$ concentration (Fig. 1D).

Cd treatments did not significantly change the root DW, and the mycorrhization did not influence this parameter at any treatment, including the control (Fig. 2A). By contrast, the leaf DW appeared to be lowered by the mycorrhization per se, and not by Cd treatments (Fig. 2B). In the case of $\mathrm{As}^{\mathrm{V}}$, a significant decrease in DW of the nonmycorrhized roots resulted from both treatments, which, on the other hand, did not significantly affect this parameter in Fm plants.
When treated with $1 \mu \mathrm{M} \mathrm{As}{ }^{\mathrm{V}}$, the mycorrhized roots showed a DW much higher in comparison with non-mycorrhized ones (Fig. 2C). In leaves, as with $\mathrm{Cd}$, no apparent effects of $\mathrm{As}^{\mathrm{V}}$ treatment were observed, and only the mycorrhization in itself induced a significant decrease in DW (Fig. 2D).

\subsection{Levels of glutathione (GSH) and phytochelatins (PCS) in roots and leaves}

GSH concentrations measured in roots and leaves of metal(loid)untreated ( $\mathrm{Cd} / \mathrm{As}$ 0) non-mycorrhized plants (no Fm) were, on average, $28.5 \pm 9.4$ and $47.4 \pm 17.6 \mathrm{nmol} \mathrm{SH} \mathrm{g}{ }^{-1} \mathrm{FW}$, respectively (Fig. 3). The mycorrhization process per se led to a strong increase of GSH content in roots, both in the absence and in the presence of the metal(loid)s (Fig. 3A, C). Also in leaves, except for those from untreated and $30 \mu \mathrm{M}$ As ${ }^{\mathrm{V}}$-treated plants, an increase in GSH content in mycorrhized plants compared with non-mycorrhized ones was observed (Fig. 3B, D). Indeed, with 1 and $30 \mu \mathrm{M}$ Cd the increase in leaf GSH of Fm plants was very high compared with nonmycorrhized ones, that is at least 5-times more (Fig. 3B). Cd treatments in non-mycorrhized and Fm plants failed to change the root GSH content compared with control, except for an increase in non-

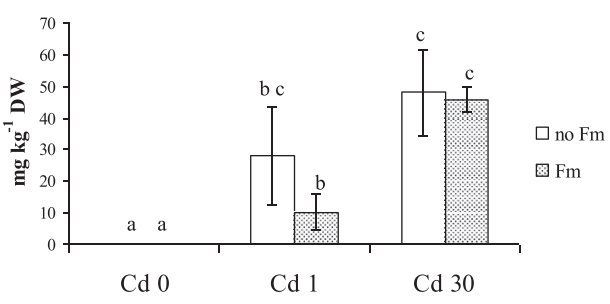

C

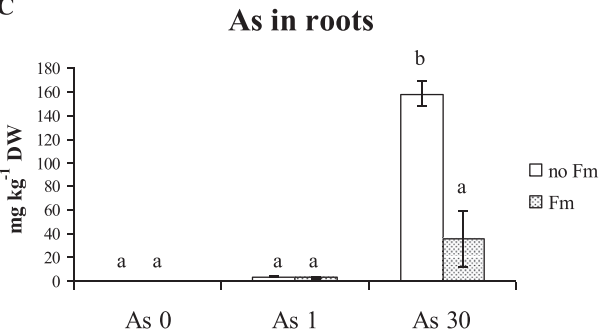

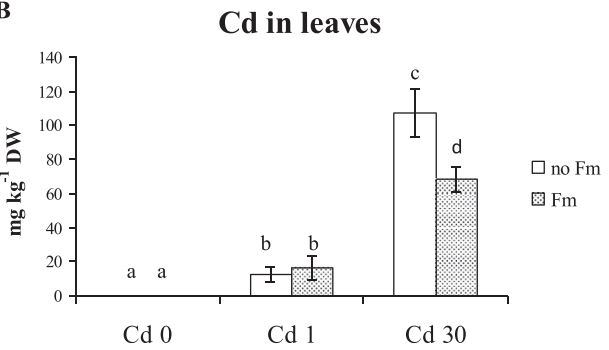

D

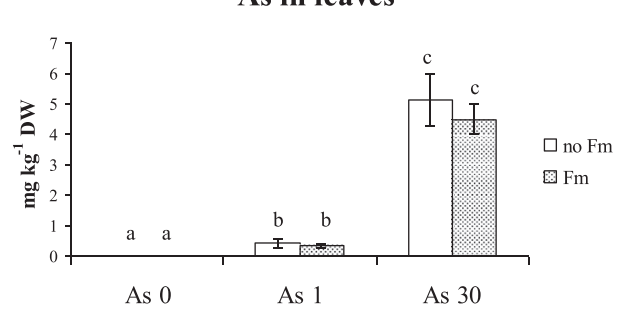

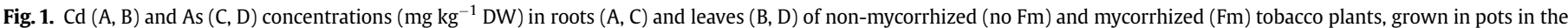

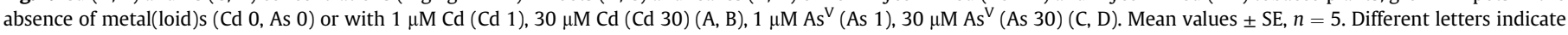
significant differences at $\mathrm{p}<0.05$ (two-way ANOVA followed by LSD test). 


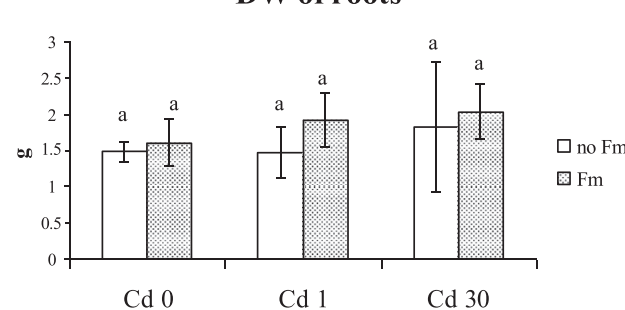

C

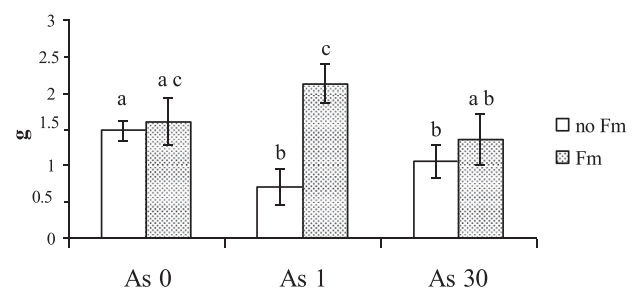

B

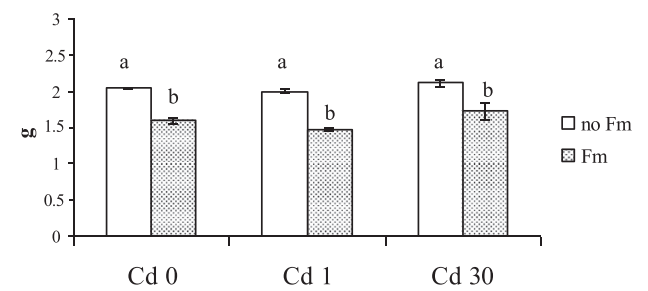

D

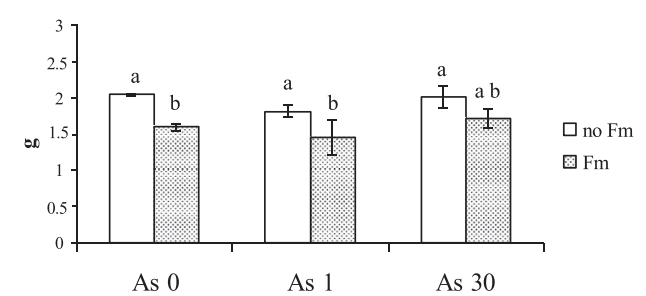

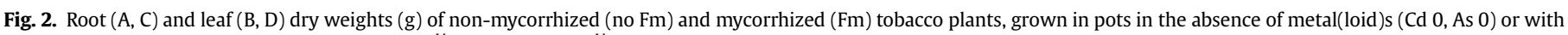

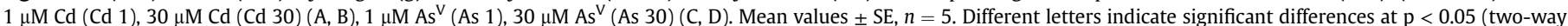
ANOVA followed by LSD test).

mycorrhized roots when the metal was supplied at the highest concentration (Fig. 3A). Likewise, $\mathrm{As}^{\mathrm{V}}$ determined a significant GSH increase in roots only at $30 \mu \mathrm{M}$ (Fig. 3C). In leaves of nonmycorrhized plants, $\mathrm{Cd}$ and $\mathrm{As}^{\mathrm{V}}$ exposure gave rise to a $\mathrm{GSH}$ decrease under $1 \mu \mathrm{M}$ treatment, followed by a return to control levels at the highest concentration (Fig. 3B, D). Differently, in leaves from Fm plants, the Cd treatment yielded a significant increase in the GSH level only at $30 \mu \mathrm{M}$ (Fig. 3B), whereas $\mathrm{As}^{\mathrm{V}}$ did not lead to any significant effect on GSH content at either concentration (Fig. 3D).

PCs were never detected in non-Cd/As ${ }^{\mathrm{V}}$-treated plants (controls), but their synthesis was always induced by both concentrations of $\mathrm{Cd}$ and $\mathrm{As}^{\mathrm{V}}$ (Fig. 4). In roots, the mycorrhization appeared to produce a significant reduction in $\mathrm{PC}$ induction at the highest metal(loid) concentration of $30 \mu \mathrm{M}$ (Fig. 4A, C), whereas no clear effects were evidenced at $1 \mu \mathrm{M}$, where the PC content increased $(1 \mu \mathrm{M} \mathrm{Cd})$ or remained unaffected $\left(1 \mu \mathrm{M} \mathrm{As}{ }^{\mathrm{V}}\right)$ with respect to nonmycorrhized roots. The levels of PCs increased in a $\mathrm{Cd} / \mathrm{As}^{\mathrm{V}}{ }^{\mathrm{V}}$-concentration-dependent manner in non-mycorrhized roots, and a similar trend was observed in $\mathrm{As}^{\mathrm{V}}$-treated-Fm roots, while the opposite was found in Cd-treated-Fm ones (Fig. 4A, C). In leaves, the plant mycorrhization affected negatively the PC synthesis only at $30 \mu \mathrm{M} \mathrm{Cd}$, in comparison with leaves from non-mycorrhized samples, even though in plants exposed to $\mathrm{As}^{\mathrm{V}}$ a non-significant downward trend, compared with the non-mycorrhized ones, was observed (Fig. 4B, D). No differences in PC induction in response to the two metal(loid) treatments were detected in leaves from nonmycorrhized plants and, with $\mathrm{As}^{\mathrm{V}}$, also in leaves from Fm plants. By contrast, a significant $P C$ reduction was observed by increasing the Cd concentration (Fig. 4B, D).
$\mathbf{A}$

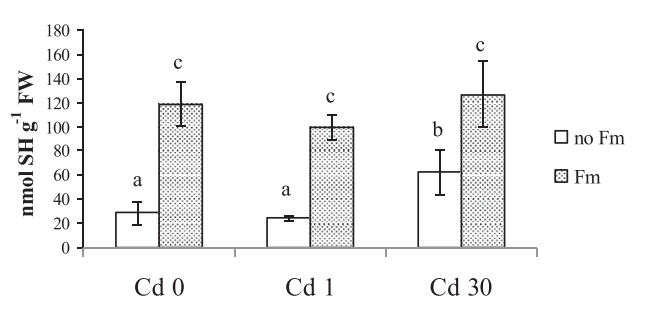

C

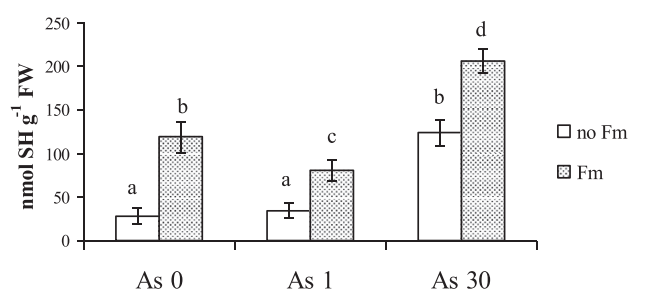

B

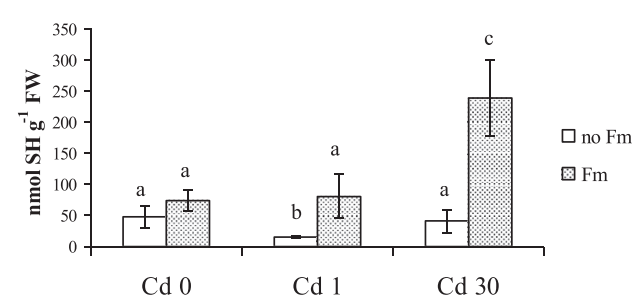

D

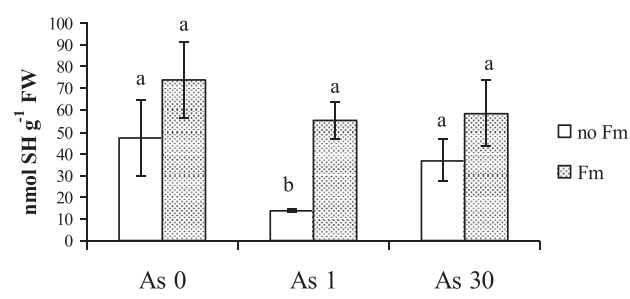

Fig. 3. GSH concentration (nmol SH g ${ }^{-1} \mathrm{FW}$ ) in roots (A, C) and leaves (B, D) of non-mycorrhized (no Fm) and mycorrhized (Fm) tobacco plants, grown in pots in the absence of metal(loid)s (Cd 0, As 0) or with $1 \mu \mathrm{M} \mathrm{Cd}(\mathrm{Cd} 1), 30 \mu \mathrm{M} \mathrm{Cd}$ (Cd 30) (A, B), $1 \mu \mathrm{M} \mathrm{As} \mathrm{v}^{\mathrm{V}}$ (As 1), $30 \mu \mathrm{M} \mathrm{As} \mathrm{v}^{\mathrm{V}}$ (As 30) (C, D). Mean values \pm SE, $n=5$. Different letters indicate significant differences at $\mathrm{p}<0.05$ (two-way ANOVA followed by LSD test). 
A

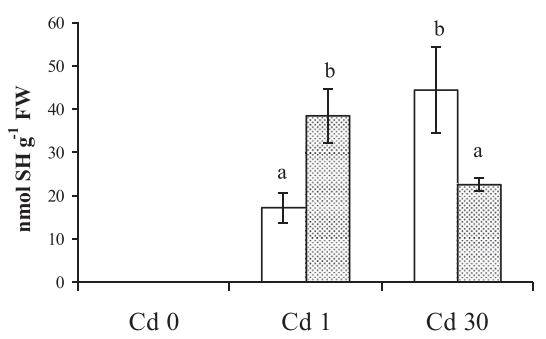

C

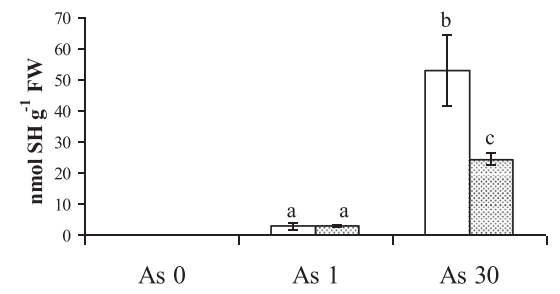

B

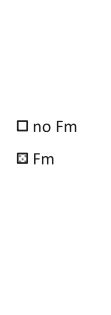

$$
\text { D }
$$

PCs in leaves

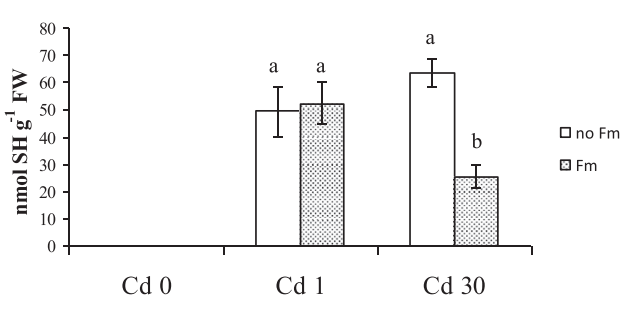

D
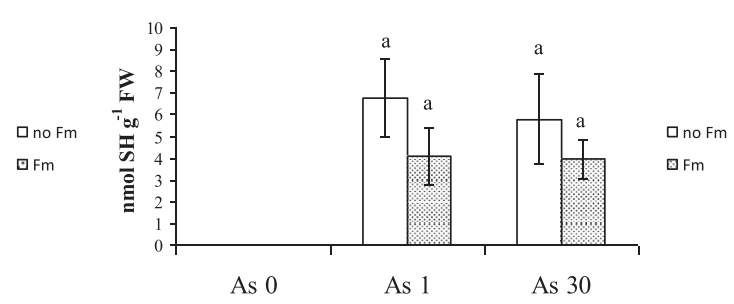

Fig. 4. Phytochelatin (PC) concentrations ( $\mathrm{nmol} \mathrm{SH} \mathrm{g}{ }^{-1} \mathrm{FW}$ ) in roots ( $\left.\mathrm{A}, \mathrm{C}\right)$ and leaves (B, D) of non-mycorrhized (no Fm) and mycorrhized (Fm) tobacco plants, grown in pots in the absence of metal(loid)s (Cd 0, As 0) or with $1 \mu \mathrm{M} \mathrm{Cd}\left(\mathrm{Cd}\right.$ 1), $30 \mu \mathrm{M} \mathrm{Cd}(\mathrm{Cd} 30)(\mathrm{A}, \mathrm{B}), 1 \mu \mathrm{M} \mathrm{As} \mathrm{v}^{\mathrm{V}}$ (As 1), $30 \mu \mathrm{M} \mathrm{As} \mathrm{N}^{\mathrm{V}}$ (As 30) (C, D). Mean values $\pm \mathrm{SE}, n=5$. Different letters indicate significant differences at $\mathrm{p}<0.05$ (two-way ANOVA followed by LSD test).

\section{Discussion}

At the end of the pot culture, the percentages of mycorrhizal colonization were medium-high (according to Trouvelot et al., 1986), both in the presence and in the absence of metal(loid)s (Table 1). By comparing the final $\mathrm{M} \%$ and $\mathrm{A} \%$ with their initial values, it can be deduced that the mycorrhizal intraradical growth was slowed by Cd treatments, while $\mathrm{As}^{\mathrm{V}}$ did not affect it at the given concentrations. Furthermore, both final $\mathrm{M} \%$ and $\mathrm{A} \%$ were significantly lower only in the roots of Cd-treated Fm plants if compared with control ones: accordingly, the fungus could suffer the effects of $\mathrm{Cd}$ toxicity, but this does not seem to happen with $\mathrm{As}^{\mathrm{V}}$.

Our results also demonstrate that the presence of Fm may significantly influence both $\mathrm{Cd}$ accumulation in leaves and $\mathrm{As}^{\mathrm{V}}$ uptake in roots of $N$. tabacum plants (Fig. 1). In fact, after 28 days of treatment with $30 \mu \mathrm{M} \mathrm{Cd}$, this metal was preferentially accumulated in leaves of non-mycorrhized plants, at a concentration of more than twice of that found in roots, and the mycorrhization reduced the Cd level in the aerial organs (Fig. 1B). Following the $30 \mu \mathrm{M}$ Cd exposure, an approx. $40 \%$ reduction of Cd content and a decrease of about $18 \%$ in the leaf DW, compared to leaves of nonmycorrhized plants, were detected (Figs. 1 and 2B). Thus, the just described decrease might be given by a real ability of the fungus to reduce - possibly by immobilization/exclusion mechanisms - the accumulation of high metal concentrations in tobacco leaves. Conversely, when the metal was supplied at $1 \mu \mathrm{M}$, its amount in the leaves of Fm plants did not significantly change compared with non-mycorrhized ones (Fig. 1B). Cd levels detected in leaves of nonmycorrhized plants were always higher than those found in tobacco leaves by Lugon-Moulin et al. (2006a) (up to $6.78 \mathrm{mg} \mathrm{kg}^{-1}$ DW); however, different growth media may considerably affect the metal bioavailability. Our plants, after the first two months of culture, continued to grow in pots containing only quartz sand as the solid substrate, i.e. an inert material on which the metal(loid)s are not adsorbed. The metal(loid) concentration actually available to the plant was, therefore, certainly higher than in a soil with a similar $\mathrm{pH}$. In addition, we found a different pattern of $\mathrm{Cd}$ accumulation in non-mycorrhized plants compared with that shown in tobacco by other authors, e.g. Wojas et al. (2010b), who found a higher content of $\mathrm{Cd}$ in roots than in leaves. However, in this case both the metal concentration supplied (according to Janoušková et al., 2005) and the exposure-time have to be considered, because this species tends to accumulate higher levels of $\mathrm{Cd}$ in leaves than in the roots if the exposure-time lasts more than two weeks (G. Falasca et al., unpublished). In our experiments, the exposure-time to $\mathrm{Cd}$ (28 days) was longer compared with that used by Wojas et al. (2010b) (2 days). Accordingly, Janoušková et al. (2007) found leaf/root Cd concentration ratios higher than 2 in commercial cvs. of tobacco plants grown for 16 weeks in different soils containing the metal. It is interesting to note that a leaf concentration over $100 \mathrm{mg} \mathrm{kg}^{-1}$ DW (i.e. similar to that which we found in the leaves of non-mycorrhized plants treated with $30 \mu \mathrm{M}$ Cd; Fig. 1B) is used as a threshold value for $\mathrm{Cd}$ hyperaccumulation (Baker et al., 2000): thus, tobacco, which is not a hyperaccumulator species, is however potentially capable of concentrating a substantial amount of this toxic metal in its aerial part, over a relatively long lapse of time.

From the present data, root DW and Cd concentration measurements (Figs. 1 and 2A) indicate that the access of $\mathrm{Cd}$ ions into the root does not seem to be significantly influenced by the AM fungus. Our hypothesis is that the symbiotic association with the F. mosseae may affect the root-to-leaf $\mathrm{Cd}$ translocation, limiting it in case of an increase of the exogenous metal concentration. Other authors have suggested that in mycorrhized plants a reduced longdistance translocation of the metal may take place, as shown by an increased root/leaf ratio of $\mathrm{Cd}$ with respect to non-mycorrhized ones (Garg and Bhandari, 2014, and references therein). In our experiments this ratio increased when Cd was supplied at $30 \mu \mathrm{M}$ (i.e. from 0.45 in non-mycorrhized plants to 0.67 in $\mathrm{Fm}$ ones; Fig. 1A, B). Moreover, considering that after treatment with $30 \mu \mathrm{M}$ $\mathrm{Cd}$, the PC level detected in Fm roots was significantly lower than in non-mycorrhized roots (Fig. 4A), even though the Cd concentration remained the same, the PC pool aimed at translocating Cd towards the leaves should be less, in accordance with a reduced transfer of $\mathrm{Cd}$ to these organs. Considering that the intraradical fungal growth seemed slowed by $\mathrm{Cd}$ presence, mostly at the highest concentration (Table 1B), we are inclined to believe that part of this metal might be sequestered by the intraradical mycelium of $F$. mosseae. Further 
studies are, however, required, especially in adult tobacco plants. In any case, the reduced level of PCs detected in leaves of Fm plants treated with $30 \mu \mathrm{M} \mathrm{Cd}$, compared with non-mycorrhized ones (Fig. 4B), can be linked to the lower Cd concentration in these organs (Fig. 1B). At an exogenous Cd concentration thirty-fold lower, non-mycorrhized plants were probably able to detoxify almost completely the metal using the PC-detoxification-strategy, and the role of the fungus was possibly less important: indeed, it helped to improve the plant's defensive potential, i.e. GSH synthesis, and consequently PC synthesis, in Fm root cells.

Concerning the As accumulation, contrary to $\mathrm{Cd}$, high levels of this metalloid were measured in non-mycorrhized roots, when supplied at the highest concentration (Fig. 1C). This is in accord with Hua et al. (2009), who found a significantly higher concentration of As in roots of non-mycorrhized adult plants of tobacco, grown for 13 weeks in As-contaminated soil, when compared with leaves. Our results show that, when $\mathrm{As}^{\mathrm{V}}$ was supplied at $30 \mu \mathrm{M}$, the mycorrhization led to a marked reduction of As content in roots, while the process did not influence As content in leaves (Fig. 1C, D). $\mathrm{Fm}$ effectively limited the uptake of elevated $\mathrm{As}^{\mathrm{V}}$ concentrations through the roots, presumably immobilizing it in the cell wall or inside the extraradical mycelium, whose growth is not expected to change significantly in the presence of $\mathrm{As}^{\mathrm{V}}$, as is the case with the intraradical part. Another possible explanation may be related to a $\mathrm{pH}$ decrease in the rhizosphere, because AM fungi exude organic acids to cope with metal(loid) toxicity (Garg and Bhandari, 2014) and also modify the amount and composition of root exudates, thus leading to a decreased availability of As (Hua et al., 2009). Not least, these fungi may regulate $\mathrm{P}_{\mathrm{i}}$ uptake, so as to downregulate $\mathrm{As} \mathrm{V}^{\mathrm{V}}$ transport into the host (Xu et al., 2008). In fact, $\mathrm{P}_{\mathrm{i}}$ and $\mathrm{As}^{\mathrm{V}}$ are chemical analogs and are translocated competitively across the plasma membrane via the same system, that is high-affinity phosphate transporters (Meharg and Macnair, 1990, 1992), some of which have been identified in tobacco (Kai et al., 2002). These transporters also seem active both at the hypha-soil and hypharoot cell interface during the symbiotic interaction (Benedetto et al., 2005; Carbonnel and Gutjahr, 2014). With $1 \mu \mathrm{M} \mathrm{As}{ }^{\mathrm{V}}$, however, the mycorrhized roots' DW was more than two-fold higher than that of non-mycorrhized ones (Fig. 2C), probably related to a better protection due to an increased GSH level (Fig. 3C) (rather than to other fungal detoxification mechanisms): in fact, the level of PCs in these roots did not change significantly if compared with that of non-mycorrhized roots (Fig. 4C), in accordance with an unchanged endogenous As concentration (Fig. 1C). Moreover, As $\mathrm{V}^{\mathrm{at}}$ a low concentration would only compete minimally with the $P_{i}$ uptake. In leaves, As accumulation was low and similar both in nonmycorrhized and in mycorrhized plants, being only $\mathrm{As}^{\mathrm{V}}$-concentration-dependent (Fig. 1D). The leaf DWs from Fm plants were lower $\left(0\right.$ and $\left.1 \mu \mathrm{M} \mathrm{As}^{\mathrm{V}}\right)$ or similar $\left(30 \mu \mathrm{M} \mathrm{As}^{\mathrm{V}}\right)$ to those measured in non-mycorrhized ones (Fig. 2D), and a low root-to-leaf translocation ability of As was noticed, with concentration values in full accordance with those reported by Lugon-Moulin et al. (2008) (up to $8.5 \mathrm{mg} \mathrm{kg}^{-1} \mathrm{DW}$ ). Indeed, in the mycorrhized plants here investigated, the decreased As content in roots cannot be attributed to an incremented root-to-leaf translocation rate. Thus, a F. mosseae-driven restriction of As root uptake, and a general alleviation of the $A s^{V}$ toxicity given by the AM fungus should be postulated, also considering the drop of PC levels shown by the mycorrhized plants when compared with the non-mycorrhized ones, particularly in roots with the highest exogenous $\mathrm{As}^{\mathrm{V}}$ concentration (Fig. 4C), where the lower PC value may be related to the lower endogenous level of the metalloid (Fig. 1C).

Interestingly, our results show that the mycorrhization process in itself induces an enhancement of GSH concentration in roots and leaves (Fig. 3). In this regard, it is possible that mycorrhizal fungi may produce, on average, high amounts of GSH per se (Schützendübel and Polle, 2002), and then move it into the plant; however, to our knowledge, there is no information on the possible transfer of this thiol-peptide from AM fungi to the root. Independently on the presence of metal(loid)s, of course host plants benefit from AM symbiosis, primarily by enhanced $P_{i}$ uptake and, in general, by an improved overall nutritional status. In this way, as found by Giovannetti et al. (2014) in mycorrhized Lotus japonicus plants, also in our system it is possible that the AM fungus $F$. mosseae might influence the expression of plant sulfate transporter(s) and impact on the overall sulfur homeostasis, thus finally leading to a higher GSH production in planta. Indeed, GSH is reported to be in itself a good chelator of meta(loid) ions (Sanità di Toppi and Gabbrielli, 1999; Scott et al., 1993; Verbruggen et al., 2009), and thus an increase in GSH levels may partly serve also for direct Cd/As binding.

In conclusion, the endomycorrhizal symbiosis between F. mosseae and tobacco adult plants showed to increase the plant tissue content of the antioxidant GSH, as well as to reduce the accumulation of exogenously-supplied elevated concentrations of $\mathrm{Cd}$ and $\mathrm{As}^{\mathrm{V}}$ in leaves and roots, respectively. For a general application of our results it is however necessary to perform tests in the open field. This is due to the fact that in soil other interactions may change the effect of $F$. mosseae on the root absorption rate of metal(loid)s, which may also vary according to the genotype of the plants used. By choosing an appropriate combination of tobacco cvs. and AM fungal isolate, it appears possible to improve the quality of commercial tobacco material, by decreasing its internal content of highly toxic metal(loid) contaminants.

\section{Contributions}

EB and GB grew the plants, inoculated them with the AM fungus, and contributed in planning the experiments. LSdT planned the experiments, performed the thiol-peptide analyses, completed and revised the overall paper. EA set up and carried out the metal(loid) analyses. FD, LF and CTS contributed in managing the plant growth, helped in the thiol-peptide analyses, performed the statistical elaboration of the data and wrote some parts of the paper.

\section{Disclosure statement}

The authors declare that there are no conflicts of interest.

\section{Acknowledgments}

We kindly acknowledge Giuseppina Falasca ("Sapienza” Università di Roma) for tobacco seeds, Lorena Gobbo (Università di Venezia "Ca' Foscari”) for her contribution to the metal(loid) analyses, and MIUR-PRIN 2007 for funding (code 2007PKFAAT_001, "Study of the mechanisms involved in accumulation and tolerance of arsenic and cadmium in model plants, colonized or not by AM fungi").

\section{References}

Baker, A.J.M., McGrath, S.P., Reeves, R.D., Smith, J.A.C., 2000. Metal hyperaccumulator plants: a review of the ecology and physiology of a biological resource for phytoremediation of metal-polluted soils. In: Terry, N., Bãnuelos, G. (Eds.), Phytoremediation of Contaminated Soil and Water. Lewis Publishers, Boca Raton, FL, pp. 85-107.

Bedini, S., Pellegrino, E., Avio, L., Pellegrini, S., Bazzoffi, P., Argese, E., Giovannetti, M. 2009. Changes in soil aggregation and glomalin-related soil protein content as affected by the arbuscular mycorrhizal fungal species Glomus mosseae and Glomus intraradices. Soil Biol. Biochem. 41, 1491-1496.

Benedetto, A., Magurno, F., Bonfante, P., Lanfranco, L., 2005. Expression profiles of a phosphate transporter gene (GmosPT) from the endomycorrhizal fungus Glomus mosseae. Mycorrhiza 15, 620-627.

Bernard, A., 2008. Cadmium and its adverse effects on human health. Indian J. Med. 
Res. 128, 557-564.

Bernhard, D., Rossmann, A., Wick, G., 2005. Metals in cigarette smoke. IUBMB Life 57, 805-809.

Bona, E., Marsano, F., Massa, N., Cattaneo, C., Cesaro, P., Argese, E., Sanità di Toppi, L., Cavaletto, M., Berta, G., 2011. Proteomic analysis as a tool for investigating arsenic stress in Pteris vittata roots colonized or not by arbuscular mycorrhizal symbiosis. J. Proteomics 74, 1338-1350.

Carbonnel, S., Gutjahr, C., 2014. Control of arbuscular mycorrhiza development by nutrient signals. Front. Plant Sci. http://dx.doi.org/10.3389/fpls.2014.00462.

de Knecht, J.A., van Dillen, M., Koevoets, P.L.M., Schat, H., Verkleij, J.A.C., Ernst, W.H.O., 1994. Phytochelatins in cadmium-sensitive and cadmiumtolerant Silene vulgaris. Chain length distribution and sulphide incorporation. Plant Physiol. 104, 255-261.

Gamalero, E., Lingua, G., Berta, G., Glick, B.R., 2009. Beneficial role of plant growth promoting bacteria and arbuscular mycorrhizal fungi on plant responses to heavy metal stress. Can. J. Microbiol. 55, 501-514.

Garg, N., Bhandari, P., 2014. Cadmium toxicity in crop plants and its alleviation by arbuscular mycorrhizal (AM) fungi: an overview. Plant Biosyst. 148, 609-621.

Giovannetti, M., Tolosano, M., Volpe, V., Kopriva, S., Bonfante, P., 2014. Identification and functional characterization of a sulfate transporter induced by both sulfur starvation and mycorrhiza formation in Lotus japonicus. New. Phytol. 204, 609-619.

Gong, J.-M., Lee, D.A., Schroeder, J.I., 2003. Long-distance root-to-shoot transport of phytochelatins and cadmium in Arabidopsis. Proc. Natl. Acad. Sci. U. S. A. 100, 10118-10123.

González-Chávez, M.C., Carrillo-González, R., Wright, S.F., Nichols, K.A., 2004. The role of glomalin, a protein produced by arbuscular mycorrhizal fungi, in sequestering potentially toxic elements. Environ. Pollut. 130, 317-323.

Göhre, V., Paszkowski, U., 2006. Contribution of the arbuscular mycorrhizal symbiosis to heavy metal phytoremediation. Planta 223, 1115-1122.

Grill, E., Winnacker, E.-L., Zenk, M.H., 1985. Phytochelatins: the principal heavymetal complexing peptides of higher plants. Science 230, 674-676.

Hildebrandt, U., Regvar, M., Bothe, H., 2007. Arbuscular mycorrhiza and heavy metal tolerance. Phytochemistry 68, 139-146.

Hua, J., Lin, X., Yin, R., Jiang, Q., Shao, Y., 2009. Effects of arbuscular mycorrhizal fungi inoculation on arsenic accumulation by tobacco (Nicotiana tabacum L.). J. Environ. Sci. 21, 1214-1220.

IARC, 2004. Tobacco smoke and involuntary smoking. IARC Monogr. Eval. Carcinog. Risks Hum. 83, 1-1452.

IARC, 2012. Arsenic, metals, fibers and dusts. A review on human carcinogens. IARC Monogr. Eval. Carcinog. Risks Hum. 100C (41-93), 121-145.

Janoušková, M., Pavlíková, D., Macek, T., Vosátka, M., 2005. Arbuscular mycorrhiza decreases cadmium phytoextraction by transgenic tobacco with inserted metallothionein. Plant Soil 272, 29-40.

Janoušková, M., Vosátka, M., Rossi, L., Lugon-Moulin, N., 2007. Effects of arbuscular mycorrhizal inoculation on cadmium accumulation by different tobacco (Nicotiana tabacum L.) types. Appl. Soil Ecol. 35, 502-510.

Kai, M., Takazumi, K., Adachi, H., Wasaki, J., Shinano, T., Osaki, M., 2002. Cloning and characterization of four phosphate transporter cDNAs in tobacco. Plant Sci. 163, $837-846$.

Keller, C., Hammer, D., 2005. Alternatives for phytoextraction: biomass plants versus hyperaccumulators. Geophys. Res. Abstr. 7, 2nd EGU General Assembly.

Krystofova, O., Zitka, O., Krizkova, S., Hynek, D., Shestivska, V., Adam, V., Hubalek, J., Machova, M., Macek, T., Zehnalek, J., Babula, P., Havel, L., Kizek, R., 2012. Accumulation of cadmium by transgenic tobacco plants (Nicotiana tabacum L.) carrying yeast metallothionein gene revealed by electrochemistry. Int. J. Electrochem. Sci. 7, 886-907.

Liu, Y., Zhu, Y.G., Chen, B.D., Christie, P., Li, X.L., 2005. Yield and arsenate uptake of arbuscular mycorrhizal tomato colonized by Glomus mosseae BEG167 in as spiked soil under glasshouse conditions. Environ. Int. 31, 867-873.

Lugon-Moulin, N., Martin, F., Krauss, M.R., Ramey, P.B., Rossi, L., 2006a. Cadmium concentration in tobacco (Nicotiana tabacum L.) from different countries and its relationship with other elements. Chemosphere 63, 1074-1086.

Lugon-Moulin, N., Martin, F., Krauss, M.R., Ramey, P.B., Rossi, L., 2008. Arsenic concentration in tobacco leaves: a study on three commercially important tobacco (Nicotiana tabacum L.) types. Water Air Soil Pollut. 192, 315-319.

Lugon-Moulin, N., Ryan, L., Donini, P., Rossi, L., 2006b. Cadmium content of phosphate fertilizers used for tobacco production. Agron. Sustain. Dev. 26, 151-155.

Lugon-Moulin, N., Zhang, M., Gadani, F., Rossi, L., Koller, D., Krauss, M., Wagner, G.J., 2004. Critical review of the science and options for reducing cadmium in tobacco (Nicotiana tabacum L.) and other plants. Adv. Agr. 83, 111-180.

Meharg, A.A., Macnair, M.R., 1990. An altered phosphate uptake system in arsenatetolerant Holcus lanatus L. New. Phytol. 116, 29-35.

Meharg, A.A., Macnair, M.R., 1992. Suppression of the high affinity phosphate uptake system - a mechanism of arsenate tolerance in Holcus lanatus L. J. Exp. Bot. 43, 519-524.

Mendoza-Cózatl, D.G., Jobe, T.O., Hauser, F., Schroeder, J.I., 2011. Long-distance transport, vacuolar sequestration, tolerance, and transcriptional responses induced by cadmium and arsenic. Curr. Opin. Plant Biol. 14, 554-562.

Mertz, W., 1981. The essential trace elements. Science 213, 1332-1338.
Murashige, T., Skoog, F., 1962. A revised medium for rapid growth and bio assays with tobacco tissue cultures. Physiol. Plant. 15, 473-497.

Nagajyoti, P.C., Lee, K.D., Sreekanth, T.V.M., 2010. Heavy metals, occurrence and toxicity for plants: a review. Environ. Chem. Lett. 8, 199-216.

Papoyan, A., Piñeros, M., Kochian, L.V., 2007. Plant $\mathrm{Cd}^{2+}$ and $\mathrm{Zn}^{2+}$ status effects on root and shoot heavy metal accumulation in Thlaspi caerulescens. New. Phytol. $175,51-58$.

Petraglia, A., De Benedictis, M., Degola, F., Pastore, G., Calcagno, M., Ruotolo, R., Mengoni, A., Sanità di Toppi, L., 2014. The capability to synthesize phytochelatins and the presence of constitutive and functional phytochelatin synthases are ancestral (plesiomorphic) characters for basal land plants. J. Exp. Bot. 65, $1153-1163$.

Pomponi, M., Censi, V., Di Girolamo, V., De Paolis, A., Sanità di Toppi, L., Aromolo, R., Costantino, P., Cardarelli, M., 2006. Overexpression of Arabidopsis phytochelatin synthase in tobacco plants enhances $\mathrm{Cd}^{2+}$ tolerance and accumulation but not translocation to the shoot. Planta 223, 180-190.

Raab, A., Feldmann, J., Meharg, A.A., 2004. The nature of arsenic-phytochelatin complexes in Holcus lanatus and Pteris cretica. Plant Physiol. 134, 1113-1122.

Roth, U., von Roepenack-Lahaye, E., Clemens, S., 2006. Proteome changes in Arabidopsis thaliana roots upon exposure to $\mathrm{Cd}^{2+}$. J. Exp. Bot. 57, 4003-4013.

Sanità di Toppi, L., Gabbrielli, R., 1999. Response to cadmium in higher plants. Environ. Exp. Bot. 41, 105-130.

Schüßler, A., Walker, C., 2010. The Glomeromycota. A Species List with New Families and New Genera. Edinburgh \& Kew, UK. The Royal Botanic Garden; Munich, Germany: Botanische Staatssammlung Munich; Oregon, USA: Oregon State University, 13. URL: http://www.amf-phylogeny.com.

Schützendübel, A., Polle, A., 2002. Plant responses to abiotic stresses: heavy metalinduced oxidative stress and protection by mycorrhization. J. Exp. Bot. 53, 1351-1365.

Scott, N., Hatlelid, K.M., MacKenzie, N.E., Carter, D.E., 1993. Reactions of arsenic(III) and $\operatorname{arsenic}(\mathrm{V})$ species with glutathione. Chem. Res. Toxicol. 6, 102-106.

Senden, M.H.M.N., van der Meer, A.J.G.M., Verburg, T.G., Wolterbeek, H.Th, 1995. Citric acid in tomato plant roots and its effect on cadmium uptake and distribution. Plant Soil 171, 333-339.

Talano, M.A., Oller, A.L.W., González, P., González, S.O., Agostini, E., 2014. Effects of arsenate on tobacco hairy root and seedling growth, and its removal. In Vitro Cell. Dev. Biol.- Plant 50, 217-225.

Trotta, A., Falaschi, P., Cornara, L., Minganti, V., Fusconi, A., Drava, G., Berta, G., 2006 Arbuscular mycorrhizae increase the arsenic translocation factor in the as hyperaccumulating fern Pteris vittata L. Chemosphere 65, 74-81.

Trotta, A., Varese, G.C., Gnavi, E., Fusconi, A., Sampò, S., Berta, G., 1996. Interactions between the soilborne root pathogen Phytophthora nicotianae var. parasitica and the arbuscular mycorrhizal fungus Glomus mosseae in tomato plants. Plant Soil 185, 199-209.

Trouvelot, A., Kough, J.L., Gianinazzi-Pearson, V., 1986. Mesure du taux de mycorhization VA dun système radiculaire. Recherche de méthodes ïestimation ayant une signification fonctionnelle. In: Gianinazzi-Pearson, V., Gianinazzi, S. (Eds.), Physiological and Genetical Aspects of Mycorrhizae. INRA Publications, Paris, pp. 217-221.

Verbruggen, N., Hermans, C., Schat, H., 2009. Mechanisms to cope with arsenic or cadmium excess in plants. Curr. Opin. Plant Biol. 12, 364-372.

Vögeli-Lange, R., Wagner, G.J., 1990. Subcellular localization of cadmium and cadmium-binding peptides in tobacco leaves. Implication of a transport function for cadmium-binding peptides. Plant Physiol. 92, 1086-1093.

Vögeli-Lange, R., Wagner, G.J., 1996. Relationship between cadmium, glutathione and cadmium-binding peptides (phytochelatins) in leaves of intact tobacco seedlings. Plant Sci. 114, 11-18.

Wojas, S., Clemens, S., Hennig, J., Skłodowska, A., Kopera, E., Schat, H., Bal, W., Antosiewicz, D.M., 2008. Overexpression of phytochelatin synthase in tobacco: distinctive effects of AtPCS1 and CePCS genes on plant response to cadmium. J. Exp. Bot. 59, 2205-2219.

Wojas, S., Clemens, S., Skłodowska, A., Antosiewicz, D.M., 2010a. Arsenic response of AtPCS1- and CePCS-expressing plants - effects of external As(V) concentration on As-accumulation pattern and NPT metabolism. J. Plant Physiol. 167, 169-175.

Wojas, S., Ruszczyńska, A., Bulska, E., Clemens, S., Antosiewicz, D.M., 2010b. The role of subcellular distribution of cadmium and phytochelatins in the generation of distinct phenotypes of AtPCS1- and CePCS3- expressing tobacco. J. Plant Physiol. 167, 981-988.

Xu, P., Christie, P., Liu, Y., Zhang, J., Li, X., 2008. The arbuscular mycorrhizal fungus Glomus mosseae can enhance arsenic tolerance in Medicago truncatula by increasing plant phosphorus status and restricting arsenate uptake. Environ. Pollut. 156, 215-220.

Xu, X.Y., McGrath, S.P., Zhao, F.J., 2007. Rapid reduction of arsenate in the medium mediated by plant roots. New. Phytol. 176, 590-599.

Yadav, S.K., 2010. Heavy metals toxicity in plants: an overview on the role of glutathione and phytochelatins in heavy metal stress tolerance of plants. South Afr. J. Bot. 76, 167-179.

Zhao, F.J., Ma, J.F., Meharg, A.A., McGrath, S.P., 2009. Arsenic uptake and metabolism in plants. New. Phytol. 181, 777-794. 